\title{
A FIELD TRIAL ON THE EFFECT OF PROPYLENE GLYCOL ON DAIRY NANNY GOATS WELFARE DURING CRITICAL TRANSITION STAGES
}

\author{
H.R. Behery ${ }^{1}$, A.A. Al-Mowafy ${ }^{1}$, M. M. El- Nahhrawy ${ }^{2}$, A. L. I. Desoky ${ }^{1}$, E.I. Khalifa ${ }^{1}$ and \\ NohaT. H. Tag Eldin ${ }^{3}$
}

${ }^{1}$ Sheep and Goats Research Department, Animal Production Research Institute, Minstry of Agriculture, Dokki, Giza, Egypt.

${ }^{2}$ Animal Nutrition Research Department, Animal Production Research Institute, Minstry of Agriculture, Dokki, Giza, Egypt.

${ }^{3}$ Animal Production Department, Facultry of Agriculture, Damietta University, Damietta, Egypt.

(Received 3/11/2019, accepted 17/12/2019)

\section{SUMMARY}

ighteen lactating Zaraibi goats were designed experiment to determine the effects of three different
rations (isocaloric and isonitrogenic) supplemented with different levels of propylene glycol (PG)
on goats welfare during critical transition stages. The three rations formed as PG0, PG1 and PG2 which alternative of 0,10 and $20 \%$ of concentrate feed mixture (CFM), respectively. These rations were prepared and continued feeding to the three dairy nanny goat groups ( $\mathrm{n}=6$ each group) from flushing up to 21 st weeks of lactation. The body weight, measurements post-parturition, milk production such as suckling and milking amount, feed consumption and blood samples were evaluated. Then, economical efficiency was assayed for selling milk yield. Experimental results indicated that both dietary groups included PG1 and PG2 showed higher $(\mathrm{P}<0.05)$ body weight through transition periods. Supplementation of $\mathrm{PG}$ in ration as 10 or $20 \%$ could be improved measurements post-parturition more than goat group untreated with PG. The milk production such as suckling and lactating of the PG groups were significantly higher than that of the control group $(\mathrm{P}<0.05)$. The PG1 and PG2 goats had lower $(\mathrm{P}<0.05)$ effect on dry matter intake (DMI) than PG0 during transition periods. The effect of different levels of PG containing rations on the main blood serum of goat such as glucose, non-esterified fatty acids (NEFA), $\beta$-hydroxyl butyric acid ( $\beta$ HBA) and blood urea nitrogen (BUN) were varied through pre / post-partum. Hence, concentration of serum glucose in the PG groups were significantly higher than that of the control group $(\mathrm{P}<0.05)$ through pre / post-partum. Conversely, the concentrations of NEFA, $\beta \mathrm{HBA}$ and BUN in the PG groups were lower than those of the control group $(\mathrm{P}<0.05)$ through pre / post-partum. In addition, commercial milk amount, selling price of milk and total price was lower in PG1 and PG2 groups than PG0 thus, PG showed higher economical value than control goats. It can be concluded that inclusion of PG instead of 10 or $20 \%$ of CFM in the dairy nanny goats' diet lead to economic benefit positively such as body weight, reproductive performance post-partum, milk production, feed consumption and blood metabolic. Generally, supplementation with PG might have been attained among dairy goats on lower planes of nutrition or otherwise less optimally managed and also prevents any negative risk on goats healthy during critical transition periods.

Keywords:Propylene glycol, critical transition periods, feeding, productive performance and dairy goats.

\section{INTRODUCTION}

The transition periods from flushing, trimester of gestation to lactation are the most critical stages and metabolically challenging periods in the life cycle of dairy animals. Several nutritional strategies have been specified to improve the adaptation of transition periods of dairy goats. For instance the deficiency of energy sources cause the atony or hypotony of ovaries, uterus and udder, this is the main cause of its late involution of reproductive and productive performance (Kristensen and Raun, 2007). During transition, the amount of energy required for maintenance of body tissues and milk production exceeds the amount of energy which obtains from dietary sources (Chung et al., 2009) revealed that the high energy requirement results in a negative energy balance. Alternation of glucogenic nutrient and its precursors in the composition of feedstuffs are improved the metabolic status and help to reduce 


\section{Behery et al.}

production costs through transition periods. Hence, propylene glycol (PG) is a glucoplastic substance for ruminants, which has been used in the treatment of ketosis and still used today (Lien et al., 2010) and defined that PG riches in energy (up to 4.7 Mcal NE/L), rapidly absorbed in the rumen approximately 80$90 \%$ and usually metabolized at 3hours after feeding. In addition, Shankare Gowda et al. (2013) indicated that PG may be used to reduce the negative energy balance after calving and limiting the risk of ketosis and fatty liver. According to later authors, the glucogenic action of PG is discussed by the previous authors they noticed that PG is metabolized in the rumen to lactic acid and propionic acid, which are converted to glucose by hepatocytes which absorbed by the rumen wall or from the gastrointestinal tract and is converted to glucose by the liver. Furthermore, Cruz et al. (2014) found that a successful use of PG was to reduce plasma concentrations of free fatty acids, urea and increased plasma concentrations of glucose, insulin, cholesterol and Insulin- growth factor 1 (IGF-I). The PG makes a small positive contribution to energy status (Hussein et al., 2015) and it is known to be anti-ketogenic by increasing plasma glucose concentrations through decreased peripheral tissue glucose demand, reducing nonesterified fatty acids (NEFA) and liver triglyceride levels which resulting in a decreasing concentrations of $ß$-hydroxybutyric acid (BHBA) in plasma. In addition, Nalawade et al. (2015) discussed that PG had the antibacterial and antifungal effects on many bacteria species. Also, numerous of trials have been conducted that using various PG dosages, in dairy cows (Mecitoğlu et al., 2017). Also, administration in dairy sheep (Santos et al., 2017) caused interpretation of energy balance. On the other hand, Akamatsu et al. (2018) suggested that PG prevents liver dysfunction related to insufficiency of bile excretion occurs in cows with ketosis. Newly, El-Sawah et al. (2019) discussed that addition of PG to feedstuffs could be improved quality of milk goats manufacturing.

Therefore, this study was designed to investigate the effects of replacing either 10 or $20 \%$ of CFM by PG on transition periods and its production and reproduction parameters of dairy Zaraibi goats.

\section{MATERIALS AND METHODS}

All dairy goats used in this experiment relevant to El-Serw Research Station belonging to Animal Production Research Institute (APRI), Agriculture Research Center, Ministry of Agriculture, Egypt. The experimental period was carried out from first of October 2017 to August 2018.

\section{Experimental animals:}

Eighteen dairy Zaraibi goats in 3rd lactation season (appeared healthy and clinically free of diseases) were divided into three similar groups (6/ each) based on average body weight (ABW). They had ABW up to $36.53 \pm 0.18 \mathrm{~kg}$ and aged 39.00 months. All goats were used pre-21 days of mating season to evaluate the effect of supplementation either 10 or $20 \%$ of PG instead of 10 or $20 \%$ CFM in ration offered daily to goats.

\section{Feeding groups:}

Dairy goats in the1stgroup which served as a control (PG0) without any addition of PG, received 50\% $\mathrm{CFM}+50 \%$ roughage [as berseem hay $(\mathrm{BH})$ and rice straws $(\mathrm{RS})]$. Goats in the $2^{\text {nd }}$ group (PG1) were received $40 \% \mathrm{CFM}+50 \%$ roughage (as $\mathrm{BH}$ and $\mathrm{RS})+10 \% \mathrm{PG}$. Goats in the $3^{\text {rd }}$ group (PG2) were fed $30 \% \mathrm{CFM}+50 \%$ roughage (as BH and RS) $+20 \% \mathrm{PG}$. Each experimental group was fed individually and the feed provided to the goats was balanced to meet their needs, in compliance with National Research Council recommendations (NRC, 2007). Fresh water and mineral blocks were available as free choice all trial period. All goats were received rations daily at 9 a.m. and 4 p.m. The chemical compositions of base feedstuffs (as CFM, BH and RS) and PG0, PG1 and PG2 were analyzed according to AOAC (2007) as shown in Tables (1 and 2), respectively. Neutral detergent fiber (NDF), Acid Detergent Fiber (ADF) and Acid Detergent Lignin (ADL) were determined according to the methods of Van Soest et al. (1991). Hemicellulosey calculated as NDF - ADF and cellulose as ADF - ADL (Rinne et al., 1997), total digestible nutrients $(\mathrm{TDN})=129.39-0.9419(\mathrm{CF}+\mathrm{NFE})$, digestible crude protein $(\mathrm{DCP})=0.9596(\mathrm{CP})-$ 3.55 , digestible energy $(\mathrm{DE})=0.04409(\mathrm{TDN} \%)$, metabolizable energy $(\mathrm{ME})=1.01(\mathrm{DE})-0.45$ and net energy $(\mathrm{NE})=0.0245(\mathrm{TDN} \%)-0.12$ according to NRC (2007). 
Egyptian J. Nutrition and Feeds (2020)

Table (1): Chemical analysis of ration ingredients.

\begin{tabular}{lccc}
\hline Item & \multicolumn{3}{c}{ Ration ingredients } \\
\cline { 2 - 4 } & CFM & BH & RS \\
\hline Chemical analysis \% on DM: & & & 78.33 \\
OM & 87.77 & 13.15 & 2.94 \\
CP & 14.42 & 30.91 & 35.82 \\
CF & 10.07 & 2.33 & 2.24 \\
EE & 2.42 & 41.26 & 37.33 \\
NFE & 60.86 & 12.35 & 21.67 \\
Ash & 12.23 & & \\
Fiber fraction \% on DM: & & 55.88 & 69.48 \\
NDF & 42.95 & 43.29 & 43.95 \\
ADF & 17.29 & 36.96 & 35.85 \\
ADL & 5.79 & 12.59 & 25.53 \\
Hemicelluloses & 25.66 & 6.33 & 8.10 \\
Celluloses & 11.50 & & \\
Feeding values \% on DM: & & 61.41 & 60.49 \\
TDN & 62.75 & 9.07 & -1.35 \\
DCP & 10.29 & 2.71 & 2.67 \\
DE (M cal/kg DM) & 2.76 & 2.29 & 2.25 \\
ME (M cal/kg DM) & 2.34 & 1.38 & 1.36 \\
NE (M cal/kg DM) & 1.42 & & \\
\hline
\end{tabular}

Table (2): Chemical analysis of the experimental rations.

\begin{tabular}{lccc}
\hline Item & \multicolumn{3}{c}{ Experimental rations } \\
\cline { 2 - 4 } Chemical analysis \% on DM: & PG0 & PG1 \\
OM & 86.59 & 81.50 & 79.29 \\
CP & 13.66 & 13.45 & 13.35 \\
CF & 25.49 & 24.52 & 23.14 \\
EE & 2.33 & 2.78 & 2.67 \\
NFE & 45.11 & 40.75 & 40.13 \\
Ash & 13.41 & 18.49 & 20.71 \\
Fiber fraction \% of DM: & & & \\
NDF & 48.24 & 45.59 & 43.20 \\
ADF & 39.11 & 37.55 & 35.21 \\
ADL & 20.38 & 19.56 & 18.34 \\
Hemicelluloses & 9.13 & 8.04 & 7.99 \\
Celluloses & 18.83 & 17.99 & 16.87 \\
Feeding values \% of DM: & & & \\
TDN & 62.89 & 67.91 & 69.80 \\
DCP & 9.56 & 9.36 & 9.26 \\
DE (M cal/kg DM) & 2.77 & 2.99 & 3.08 \\
ME (M cal/kg DM) & 2.35 & 2.57 & 2.66 \\
NE (M cal/kg DM) & 1.42 & 1.54 & 1.59 \\
\hline
\end{tabular}

PG0= control treatment without PG

$\mathrm{PG} 1=$ ration contained $10 \% \mathrm{PG}$.

$\mathrm{PG} 2=$ ration contained $20 \% \mathrm{PG}$.

\section{Experimental procedures:}

\section{Body weight during critical transition stages:}

All does were weighed using a digital scale (PN-440 sheep and goat Scale). Then, body weight of each nanny goat was taken at 21 days post-mating, pre- trimester (at 100 days of gestation), at parturition (post- 3 days), at start of suckling and milking (at 90 days) and at finally weeks of lactation (post- 21 weeks). 


\section{Behery et al.}

\section{Measurements post-parturition:}

Measurement post gestation was calculated as following: conception rate (number of nanny goats gravid / number of mated nanny goats). The birth types; as single, twins and triplet birth and litter size (number of total born kids /number of nanny goats kidded $\times 100$ ).

\section{Milk production:}

\section{Suckling amount:}

Samples of suckling milk from each goat were collected up to 90 days after parturition. Then, the amount of suckling milk was estimated by oxytocin method that described by Khalifa et al. (2016B).

\section{Milking yield:}

Milk yield from each goat were recorded weekly up to 21 weeks of lactation season. Then, hand milking was occurred at $5.00 \mathrm{am}$ and at $5.00 \mathrm{pm}$. At the day of evaluated (at end of week) the milk harvest in the morning (which kept at $5^{\circ} \mathrm{C}$ ) from each goat / trial group was added to the evening cooled milk and well mixed as one amount. Then, this amount of obtained milk (morning plus evening amount /doe) was multiplied in 7 days to give milk harvest weekly/ each dairy doe. Then, weekly average of milk amount of PG0, PG1 and PG2 groups were evaluated.

\section{Feed consumption:}

The average of feed consumption was estimated individually three times for each doe (at early, middle and late) through each critical transition period. It was measured by consumption diets throughout 24 hours; the feed was supplied daily (a known quantity of trial rations) and the daily remains were recorded at the previous day in the morning.

\section{Blood samples:}

Blood samples were collected from all goats at 10th day prepartum and at 40th day postpartum. In the morning while fasting, individual blood samples $(10 \mathrm{~mL} / \mathrm{goat})$ were taken from the jugular vein and centrifuged at $3500 \times \mathrm{g}$ for $15 \mathrm{~min}$ then, after two hours of drawing and the sera were frozen at $-20{ }^{\circ} \mathrm{C}$ until analysis. The blood parameters were determined on each individual sample of serum using commercial kits (IL Company, Lexington, MA, USA; RANDOX Laboratories LTD., Crumlin, United Kingdom). The following energetic metabolism parameters were determined: Glucose, non esterified fatty acids (NEFA), total cholesterol, triglycerides and $\beta$-hydroxyl butyric acid ( $\beta$ HBA). The following protein metabolism parameters were determined: total protein, creatinine, blood urea nitrogen (BUN) and creatine kinase (CK). The following hepatic functionality parameters were determined: Aspartate aminotransferase (AST) and alanine aminotransferase (ALT).

\section{Economical efficiency:}

The economical efficiency was calculated according to the local market price of diet ingredients and milk up to 21 weeks of lactation as following:

Money output (price of selling milk) $\div$ input (total price of feed consumed) $\times 100$. In addition, the economical efficiency (\%) relative to control with PG1 or PG2 was calculated as following:

The economical efficiency amount of PG1 or PG2 - economical efficiency amount of PG0 $\div$ economical efficiency amount of PG0 $\times 100+100$ (conceder economical efficiency of PG0 is attained $100 \%)$.

\section{Statistical Analysis:}

All values were expressed as mean \pm SEM. Statistical evaluation was performed by one-way analysis of variance (ANOVA) followed by the Duncan post hoc test to determine significant differences in all the parameters among all extender types using the SPSS/PC computer program (SPSS, 2018). The significance level considered was $\mathrm{P}<0.05$.

\section{RESULTS AND DISCUSSION}

\section{Body weight of does during critical transition stages:}

The body weight average (BWA) of goats during critical transition included post-flushing at 21 days, pre- trimester (100 days of gestation), at 3 days post-partum, at began of suckling and milking and post21 weeks of lactation discussed in Table (3). The BWA of goats was higher $(\mathrm{P}<0.05)$ in goats fed PG1 and PG2 than PG0 groups at all critical transition stages. Although, the BW difference between PG1 and PG2 groups was remarkable, but it was not statistically significant during all transition periods. The most 
superb of BWA in PG1 and PG2 treatment goats may be related to available energy supplied from PG. In accord with this, Shankare Gowda et al. (2013) noticed that one of the major beneficial mechanisms of PG on energy metabolism is increasing of propionate production in the rumen by inducing an alteration in rumen microflora. Substantiation, Sadjadian et al. (2013a) proved that more propionate is the major precursor of gluconeogenesis; it leads to a better function of this metabolic pathway. Hence, these authors evidenced that BWA of goats 30 days ante-partum was $52.45 \mathrm{~kg}$ in treated group and $41.57 \mathrm{~kg}$ in controls and at 30 days after kidding the $\mathrm{ABW}$ of treatment and control goats were $46.70 \mathrm{~kg}$ and $37.97 \mathrm{~kg}$, respectively. According to Ayoub et al. (2015) PG can be absorbed in the rumen and small intestine and is an excellent precursor of glucose in gluconeogenic pathways in the liver. Then, the authors have indicated that the administration of glucose as a drench seems to be more improvement effective on body weight. In addition, Abdel-Latif et al. (2016) found that supplementation of PG at $300 \mathrm{ml}$ dissolved in 3 liters of a saline solution revealed significant differences on live body weights of Egyptian buffaloes. A complex interaction of many factors including glucose blood metabolism may be involved in the phenomenon of compensatory growth (Addah et al., 2017) increasing serum glucose is played a higher role in efficiency of feed utilization associated with compensatory growth. On the other hand, Candyrine et al. (2018) found that available energy in rations at 17.88 and $18.26 \mathrm{MJ} / \mathrm{kg}$ could be improved BWA gain for goats up to10.06 and $14.37 \mathrm{~kg}$ but, in sheep 16.77 and $23.55 \mathrm{~kg}$, respectively. At all events, ElSawah et al. (2019) observed an increase in rumen propionic acid within supplementation of PG. These authors believe that this effect cause an increasing in body weight.

Table (3): Body weight of does during critical transition stages as affected by propylene glycol supplementation.

\begin{tabular}{lccc}
\hline Item & \multicolumn{3}{c}{ Treatments } \\
\cline { 2 - 4 } & PG0 & PG1 & PG2 \\
\hline Body weight of goat $(\mathrm{kg})$ & $36.55 \pm 0.18$ & $36.49 \pm 0.16$ & $36.54 \pm 0.19$ \\
Initial body weight & $37.05 \pm 0.16$ & $37.07 \pm 0.27$ & $37.10 \pm 0.25$ \\
Post-21 days of flushing & $44.45 \pm 0.24 \mathrm{~b}$ & $48.90 \pm 0.34 \mathrm{a}$ & $49.47 \pm 0.23 \mathrm{a}$ \\
At 100 days of gestation & $37.41 \pm 0.22 \mathrm{~b}$ & $38.55 \pm 0.43 \mathrm{a}$ & $38.82 \pm 0.26 \mathrm{a}$ \\
At 3 days post- partum & $38.32 \pm 0.20 \mathrm{~b}$ & $39.45 \pm 0.40 \mathrm{a}$ & $39.52 \pm 0.25 \mathrm{a}$ \\
At began of suckling & $36.40 \pm 0.19 \mathrm{~b}$ & $37.88 \pm 0.34 \mathrm{a}$ & $38.32 \pm 0.16 \mathrm{a}$ \\
At began of milking & $35.93 \pm 0.15 \mathrm{~b}$ & $37.55 \pm 0.14 \mathrm{a}$ & $37.78 \pm 0.07 \mathrm{a}$ \\
At 21 weeks of lactation &
\end{tabular}

Means within the same row direction with different superscripts are significantly different $(P<0.05)$.

$P G O=$ control treatment without of $P G$.

$P G 1=$ ration contained $10 \%$ of $P G$.

$P G 2=$ ration contained $20 \%$ of $P G$.

\section{Post-parturition measurements:}

Reproductive post-partum measurements in PG0, PG1 and PG2 groups are presented in Table (4). Results indicated that goats in PG 1 or PG2 had higher reproductive performance than PG0 goats. Finding of, Rekik et al. (2005) noticed that the mechanisms of PG prior to and during mating increased absorption of protein in the ewes that caused an elevation of ovulation rate and consequently litter size. Also, Rekik et al. (2007) reported that goats received PG had resuming ovulation, ovulation rate and postpartum ovulation up to $74.1 \%, 1.76 \%$ and 13 goats compared to $77.8 \%, 1.25 \%$ and 12 goats in control, respectively. In addition, Viñoles et al. (2010) suggested that supplementation of PG that often used as energy additives in ruminant nutrition may acutely increase ovulation rate. Similar results were reported by Gutierrez et al. (2011) who found that PG cause a large and sustained increase in insulin concentrations that together with glucose may enhance ovulation rate. Dietary changes caused an immediate and rapid change in a range of metabolic humoral agents; including glucose and insulin (Xu et $a l ., 2015)$ thus energy diet can profoundly alter endocrine signaling pathways these changes ultimately have improved fertility. Also, Abdel-Latif et al. (2016) recorded that an improvement in reproductive parameters such as first estrus post-partum, days open and number of service per conception when PG was drenched up to $300 \mathrm{ml}$ dissolved in 3 liters of a saline solution in Egyptian buffaloes. Finally, if daily ration supplied with energy sources it could be improved reproductive performance, from this point of view Khalifa et al. (2016A) indicated that rations supplied with energy and non-energy had conception rate, fertility rate, total kids born, twining rate were 80 and 100\%, 80 and 100\%, 8 and 11 kids, 50 and $80 \%$, respectively. Also, Abdel-Gawad et al. (2017) found that energy and non energy nutrition could ameliorate litter size up to 2.8 and 2.2, respectively. PG efficiently and acutely increased insulin concentrations, with an increase by $10 \mathrm{~min}$ after mouthful that subsequently peaked by 30 min (Hackbart 


\section{Behery et al.}

et al., 2017) in cows PG is quickly converted to propionate by ruminal bacteria, absorbed directly from the rumen and rapidly increases insulin secretion from the pancreas thus, circumventing the need for conversion of absorbed PG to glucose via hepatic gluconeogenesis. Thus, the previous authors clarified that PG caused unexpected tendency for a positive effect of elevated LH on fertilization rate primarily reflects an apparent restoration of normal fertilization by increased LH with elevated insulin but, decreased fertilization rate with reduced circulating insulin caused by feed restriction.

Table (4): Measurements post-parturition as affected by propylene glycol supplementation.

\begin{tabular}{lccc}
\hline Item & & Treatments & PG2 \\
\cline { 2 - 4 } & PGO & PG1 & 6 \\
No. of goats mating & 6 & 6 & 6 \\
No. of goats gestation & 6 & 100 & 100 \\
Conception rate, $\%$ & 100 & 16 & 17 \\
No. of born kids & 14 & 15 & 17 \\
Alive kids at 0 day & 12 & 15 & 16 \\
Alive kids at weaning & 12 & 0 & 0 \\
No. of goats born single & 0 & 2 & 1 \\
No. of goats born twins & 4 & 4 & 5 \\
No. of goats born triple & 2 & 2.67 & 2.83 \\
Litter size & 2.33 & 266.67 & 283.33 \\
Kidding rate, $\%$ & 233.33 & 1 & 0 \\
No. of mortality kids & 2 & 6.25 & 0 \\
Mortality of kids $\%$ & 14.29 & 2.5 & 2.6 \\
Average kids birth weight, kg & 1.9 & 9.58 & 9.73 \\
Average weaning kids weight $\mathrm{kg}$ & 8.56 & 7.08 & 7.13 \\
Total body weight gain of kids, $\mathrm{kg}$ & 6.69 & 78.67 & 79.22 \\
*Daily body gain of kids, g & 74.33 & & \\
\hline
\end{tabular}

$P G 0=$ control treatment without of $P G$.

$P G 1=$ ration contained $10 \%$ of $P G$.

$P G 2=$ ration contained $20 \%$ of $P G$.

* Daily body gain, $g=$ total body weight gain $/ 90$ days the time of suckling $\times 1000$.

\section{Milk production:}

Figure (1) displays mean of milk production in dairy Zaraibi goats of the different of treatment during the suckling period up to 90 days and milking period up to $21^{\text {st }}$ weeks. The results reported that the milk yield of the PG1 or PG2 groups tended to be significantly greater $(\mathrm{P}<0.05)$ than that of the PG0 group. The average of milk amount in PG0, PG1 and PG2 goats through suckling were 83.45, 92.50 and $94.17 \mathrm{~kg} /$ group, moreover commercial milk was 49.74, 66.67 and $71.16 \mathrm{~kg} / \mathrm{group}$, respectively. Thus, PG supplementation appeared to have a positive effect on milk yield because of supplementation of PG can rapidly supply the energy required for milk production. Previously, Chiofalo (2007) indicated that PG caused more mean milk production (796 and $861 \mathrm{~g} / \mathrm{d}$ ) in ewes received PG at 80 and $160 \mathrm{~g} /$ ewe /day than control ewes (686 g/d), respectively. Furthermore, Lien et al. (2010) found that PG is easily and rapidly absorbed and metabolized in the rumen then, nearly $50 \%$ can be metabolized $1-2 \mathrm{~h}$ after feeding, with approximately $80-90 \%$ usually metabolized $3 \mathrm{~h}$ after feeding. The same authors demonstrated that PG could raise milk production up to $27.27 \mathrm{~kg} / \mathrm{d}$ compared to $26.63 \mathrm{~kg} / \mathrm{d}$ in control dairy cows. Also, Rukkwamsuk and Panneum, (2010) found that since PG rapidly supplies energy, this improved the degree of negative energy balance, resulting in increase milk yield by two passway gluconeogenic precursor converted to propionic acid in the rumen. In fact, a study conducted in sheep by Santos et al. (2017) and in goats by El-Sawah et al. (2019) showed that the use of PG increased the energy density of the diet, since this product is an additive, it led to greater in milk production. Mecitoğlu et al. (2017) suggested that the improvement of milk production in goats received PG in ration may be resulted in reduced serum non-esterified fatty acids (NEFA), blood urea nitrogen (BUN), ketones bodies concentration and increased plasma glucose concentration implying reduced catabolism of body tissue. 


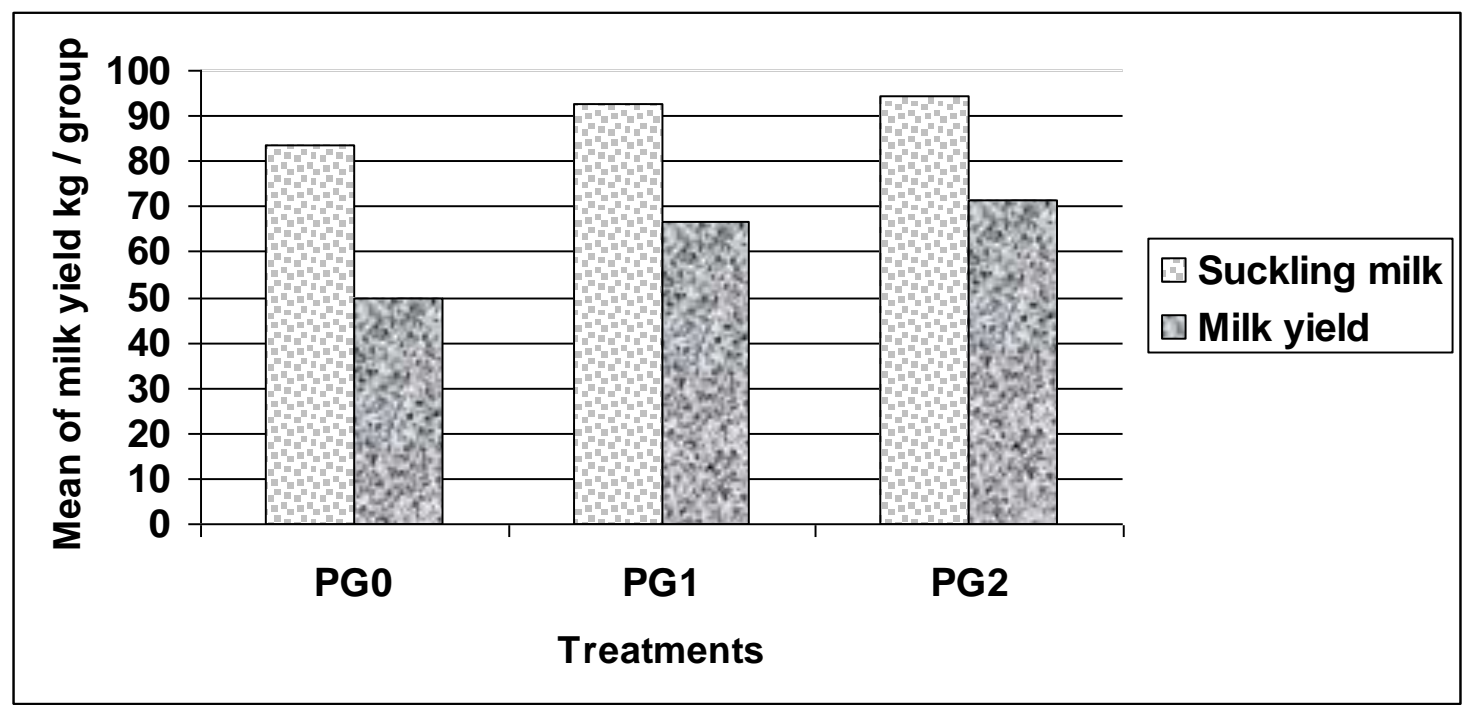

Figure (1): Mean of milk production during suckling and milking for PG0, PG1 and PG3 groups. $P G O=$ control treatment without of $P G$. $P G 1=$ ration contained $10 \%$ of $P G$.

$P G 2=$ ration contained $20 \%$ of $P G$.

\section{Feed consumption:}

The average feed consumption of goats belonging to the three dietary groups included PG1 and PG2 during critical transition stages was less $(\mathrm{P}<0.05)$ significantly than PG0 group (Table 5). However, the difference of DM intake between PG1 and PG2 was non- significant (P>0.05). Liu et al. (2009) reported that supplementation of $\mathrm{PG}$ in the early lactating cow diets had minimal $(\mathrm{P}>0.0)$ effects on feed consumption and diets with PG is beneficial in terms of improving energy status. The work by Yisehak et al. (2013) obtained significant interaction effect of diet and PG on DM intake following low consumption ration. Similar results consistent by Hamzaoui et al. (2014) who found that less dry matter intake in PG goats compared to PG0, it reached to 2.34 and $2.18 \mathrm{~kg} / \mathrm{h} / \mathrm{d}$ under thermal neutral however, under heat stress values were 1.59 and $1.38 \mathrm{~kg} / \mathrm{h} / \mathrm{d}$, respectively. It is well established that feeding PG would be beneficial to the dairy animal because 1) increasing ruminal propionate would increase the supply of this gluconeogenic substrate to the liver and 2) increasing ruminal butyrate would support the ruminal epithelial tissue perhaps reducing feed intake (Bulent, 2018). The impact of using PG on DMI is inconsistent with the current study; according to Lien et al. (2010) who reported a higher in DM intake in cows treated with $500 \mathrm{ml} \mathrm{PG}(19.72 \mathrm{~kg} / \mathrm{head} /$ day) than $18.25 \mathrm{~kg} / \mathrm{head} /$ day in control caws during early lactation. In general, the lowest DMI observed in PG groups compared with PG0 group could be explained by the difference in energy density of diets formulated (Ma et al., 2019) energy sources plays an important role in establishing nutrient requirements for animals, they were mainly based on the minimum nutrient requirement of animals.

Table (5): Feed consumption of does during critical transition stages as affected by propylene glycol supplementation.

\begin{tabular}{llll}
\hline Item & \multicolumn{3}{c}{ Treatments } \\
\cline { 2 - 4 } & \multicolumn{1}{c}{ PG0 } & PG1 & PG2 \\
\hline Feed consumption ( g/head/day) & & & \\
From Flushing to matting & $1100.83 \pm 5.06 \mathrm{a}$ & $995.33 \pm 8.22 \mathrm{~b}$ & $984.17 \pm 7.88 \mathrm{~b}$ \\
From trimester to partum & $1157.17 \pm 8.79 \mathrm{a}$ & $1087.00 \pm 6.46 \mathrm{~b}$ & $1070.50 \pm 6.03 \mathrm{~b}$ \\
From suckling to weaning & $1585.33 \pm 11.11 \mathrm{a}$ & $1527.33 \pm 10.68 \mathrm{~b}$ & $1482.83 \pm 6.86 \mathrm{~b}$ \\
At milking period up to 21 weeks & $1565.00 \pm 16.61 \mathrm{a}$ & $1480.98 \pm 12.05 \mathrm{~b}$ & $1446.05 \pm 8.24 \mathrm{~b}$ \\
\hline Means within the same row direction with different superscripts are significantly different $(\mathrm{P}<0.05)$. \\
PG0= control treatment without PG & & & \\
PG1= ration contained 10\% PG. & & & \\
PG2= ration contained 20\%PG. & & &
\end{tabular}




\section{Behery et al.}

\section{Blood serum parameters:}

Blood serum parameters during prepartum period at 10th days are shown in Table (6) and postpartum at 40th days observed in Table (7). The PG1 or PG2 showed significant higher contents of glucose than PG0 goats. An increase of glucose concentration at parturition is due to the high concentration of glucocorticoid hormones such as cortisol, which promotes an increase in hepatic glycogenolysis and gluconeogenesis from glucose precursors (Magistrelli and Rosi, 2014). The positive regulation of glucose in PG1 or PG2 goats postpartum can be attributed to the metabolic adaptation after parturition and the highest concentrations of fructosamine were observed in the initial phase of lactation (Soares et al., 2014). Probably, the last authors suggested that the significant positive correlation between lactose percentage and serum glucose level seems to be logical as $80-85 \%$ of glucose in blood is used by the mammary gland for lactose synthesis in goats. In addition, Kafilzadeha et al. (2019) indicated the positive correlation between glucose level and milk production hence, milk yield was 449 and $366 \mathrm{~g} / \mathrm{d}$ when a serum glucose level was 67.0 and $65.5 \mathrm{mg} / \mathrm{dl}$, respectively. The serum NEFA concentration pre and post parturition in the PG1 and PG2 groups was markedly different $(\mathrm{P}<0.05)$ than in the PG0 group. These results are agreement with that reported by Lien et al. (2010) who revealed that when degraded body fat large amounts of NEFA were reflected, as the quantity of NEFA exceeds the liver burden or sufficient glucose is unavailable, NEFA is converted to ketone bodies. The current study observes that PG1 and PG2 display the effect of administration of PG on $\beta$ HBA concentration of goats in the transition period as pre and post-partum. The $\mathrm{PG}$ groups recorded lower $(\mathrm{P}<0.05) \beta \mathrm{HBA}$ concentration than that in the control group during days of pre and postpartum. Barbosa et al. (2009) observed low $\beta$ HBA concentration at parturition with a gradual decrease up to the $8^{\text {th }}$ week of lactation in goats with different degrees of body condition score and related this finding also, the use of this metabolite by the mammary gland for the milk fat synthesis. Beside, Hamzaoui et al. (2014) observed lower $\beta$ HBA concentration in goats received PG than control group; it reached to 0.48 and $0.65 \mathrm{mmol} / \mathrm{L}$, respectively. The decrease $(\mathrm{P}<0.05)$ in the concentration of triglycerides in $\mathrm{PG}$ goats at the last days of gestation and in the beginning of lactation is a reflection of the increase in milk production, lower availability of free fatty acids, lipolysis to obtain energy and the greater supply of circulating triglycerides to the mammary gland to meet the milk fat synthesis (Sadjadian et al., 2013b). Analytical results revealed that the PG1 and PG2 groups had a lower $(\mathrm{P}<0.05)$ serum cholesterol concentration than that of the PG0 group during the period of 10th days prepartum to $40^{\text {th }}$ days postpartum. Barbosa et al. (2009) observed lowest serum cholesterol in the last weeks of gestation early lactation in goats. Chiofalo et al. (2009) observed lower significant values in cholesterol concentration when goats fed PG; it was $1.5 \mathrm{mmol} / \mathrm{L}$ prepartum and $1.87 \mathrm{mmol} / \mathrm{L}$ postpartum than $1.66 \mathrm{mmol} / \mathrm{L}$ prepartum and $1.92 \mathrm{mmol} / \mathrm{L}$ postpartum in control goats. Goats with PG1 and PG2 had a lower $(\mathrm{P}<0.05)$ average ALT and AST contraction than PG0 goats pre and post partum. Actually, liver plays an important role in the protein synthesis. Praveen et al. (2015) reported that ALT and AST are the specific markers to assess hepatocellular damage leading to liver cell necrosis consequently, the increase in AST and ALT indicates the hepatic origin of pregnancy toxemia which may be attributed to fat mobilization. Chiofalo et al. (2009) found that treated goat with PG could reduce the concentration of ALT and AST compared to untreated goats. As well as the PG1 and PG2 groups post partum period; could be attributed to that propylene glycol supplementation has represented a proper way to rapidly decrease lipid mobilisation and excessive formation of ketone bodies, thereby reducing the risk of fatty liver and ketosis (Prasannkumar et al., 2016). Significant correlation estimated among the milk yield and total protein concentration through $40^{\text {th }}$ of lactation. Consistent with results of this study, ElTarabany et al. (2018) recorded higher significant of serum total protein level (7.38 g/dl) with lactation up to $1.63 \mathrm{~kg} /$ day than $6.46 \mathrm{~g} / \mathrm{dl}$ of total protein with lactation at $1.11 \mathrm{~kg} / \mathrm{day}$ in Baladi goats. It was affirmed by, Akamatsu et al. (2018) that PG leading to increase concentration of protein in blood serum postpartum; this is likely the consequence of an increase of digestible proteins in the diet caused by PG provision. However, the lowest concentration of protein in serum blood of PG goats used in this work pre-partum could be explained by a possible inhibition of anabolic process in the liver (Chiofalo et al., 2009) reported that PG goats had less protein level in serum blood pre-partum up to $55.13 \mathrm{~g} / \mathrm{L}$ than control $58.80 \mathrm{~g} / \mathrm{L}$. During the postpartum period Table (9), the current trial indicates a non significant higher blood serum creatinine level at $40^{\text {th }}$ days of lactation in the PG groups than PG0 goats; this could be due to the muscular protein mobilisation in order to produce energy to confront requirement of milk production during the early lactation phase (Al-Bulushi et al., 2017). Also noteworthy is the research that has shown that creatinine level was higher in PG milking goats $(58.17 \mu \mathrm{mol} / \mathrm{L})$ than in untreated PG milking goats $(523.26 \mu \mathrm{mol} / \mathrm{L})$ by Chiofalo et al. (2009). Also, these findings are in conflict with other estimates reported by Yadav et al. (2018) who declared that higher creatinine value in animals could be related to the differences in the animals' metabolism, needs for milk production thus, creatinine is correlated with protein metabolism associated with muscle mass. Our results are together with those of Kafilzadeha et al. (2019) who found greater creatinine level $(0.81 \mathrm{mg} / \mathrm{dl})$ when milk yield was $449 \mathrm{~g} / \mathrm{d}$ 
than $0.77 \mathrm{mg} / \mathrm{dl}$ of creatinine at milk yield $366 \mathrm{~g} / \mathrm{d}$ in sheep. Significant decrease in the concentration of serum creatine kinase was observed during pre and post partum of goats this is according with Chiofalo et al. (2009) who indicated that serum creatine kinase untreated and treated PG goats were 62.63 and 42.79U/L pre-partum and reached to 89.60 and $77.70 \mathrm{U} / \mathrm{L}$ post-partum in, respectively. Thus, glucose, non esterified fatty acids (NFFA), and $\beta$-hydroxyl butyric acid ( $\beta$ HBA) are considered the mainly blood serum parameters confirmed healthy of goats and could be given an indicator about pregnancy toxemia in goats carrying multiple fetuses. Actually, pregnancy toxemia usually occurs due to a long period of negative energy balance and impaired gluconeogenesis which results in hypoglycemia, fat mobilization, ketonemia and ketonuria. Increasing in the serum $\beta \mathrm{HBA}$ and NEFA level could be attributed to the lipolysis of tissue and the release of long-chain fatty acids, which were converted by the liver into ketones in goats (Vasava et al., 2016).

Table (6): Concentration of serum metabolic in does sample prepartum at $10^{\text {th }}$ days as affected by propylene glycol supplementation.

\begin{tabular}{llcc}
\hline Serum metabolic & \multicolumn{3}{c}{ Treatments } \\
\cline { 2 - 4 } & \multicolumn{1}{c}{ PG0 } & PG1 \\
\hline Energetic metabolism & & & \\
Glucose, mmol/L & $2.72 \pm 0.05 \mathrm{~b}$ & $2.87 \pm 0.03 \mathrm{a}$ & $2.90 \pm 0.02 \mathrm{a}$ \\
NFFA, mmol/L & $0.19 \pm 0.04 \mathrm{a}$ & $0.17 \pm 0.00 \mathrm{~b}$ & $0.16 \pm 0.01 \mathrm{~b}$ \\
$\beta$ HBA, mmol/L & $0.34 \pm 0.01 \mathrm{a}$ & $0.27 \pm 0.00 \mathrm{~b}$ & $0.26 \pm 0.00 \mathrm{~b}$ \\
Triglyceride, mmol/L & $0.52 \pm 0.01 \mathrm{a}$ & $0.36 \pm 0.01 \mathrm{~b}$ & $0.35 \pm 0.00 \mathrm{~b}$ \\
Total cholesterol, mmol/L & $1.70 \pm 0.03 \mathrm{a}$ & $1.54 \pm 0.02 \mathrm{~b}$ & $1.51 \pm 0.02 \mathrm{~b}$ \\
Hepatic Functionality & & & \\
AST,U/L & $67.17 \pm 0.12 \mathrm{a}$ & $53.83 \pm 0.14 \mathrm{~b}$ & $50.83 \pm 0.07 \mathrm{~b}$ \\
ALT, U/L & $14.77 \pm 0.14 \mathrm{a}$ & $11.48 \pm 0.10 \mathrm{~b}$ & $11.29 \pm 0.13 \mathrm{~b}$ \\
Protein metabolism & & & \\
BUN, mmol/L & $4.58 \pm 0.08 \mathrm{a}$ & $4.29 \pm 0.14 \mathrm{~b}$ & $4.25 \pm 0.15 \mathrm{~b}$ \\
Total protein, g/L & $59.02 \pm 0.29 \mathrm{a}$ & $55.17 \pm 0.4 \mathrm{~b}$ & $54.99 \pm 0.14 \mathrm{~b}$ \\
Creatinine, $\mu \mathrm{mol} / \mathrm{L}$ & $62.51 \pm 0.27$ & $60.47 \pm 0.26$ & $60.11 \pm 0.11$ \\
Creatine kinase, U/L & $62.73 \pm 0.25 \mathrm{a}$ & $42.69 \pm 0.52 \mathrm{~b}$ & $41.73 \pm 0.05 \mathrm{~b}$ \\
\hline
\end{tabular}

Means within the same row direction with different superscripts are significantly different $(P<0.05)$.

$P G 0=$ control treatment without of $P G$.

$P G 1=$ ration contained $10 \%$ of $P G$.

$P G 2=$ ration contained $20 \%$ of $P G$.

Table (7): Concentration of serum metabolic in does post-partum at $40^{\text {th }}$ days as affected by propylene glycol supplementation.

\begin{tabular}{llcc}
\hline Serum metabolic & \multicolumn{3}{c}{ Treatments } \\
\cline { 2 - 4 } & \multicolumn{1}{c}{ PG0 } & PG1 & PG2 \\
\hline Energetic metabolism & & & \\
Glucose, mmol/L & $2.82 \pm 0.03 \mathrm{~b}$ & $2.93 \pm 0.02 \mathrm{a}$ & $2.98 \pm 0.03 \mathrm{a}$ \\
NFFA, mmol/L & $0.34 \pm 0.02 \mathrm{a}$ & $0.26 \pm 0.01 \mathrm{~b}$ & $0.25 \pm 0.01 \mathrm{~b}$ \\
$\beta$ HBA, mmol/L & $0.38 \pm 0.01 \mathrm{a}$ & $0.33 \pm 0.01 \mathrm{~b}$ & $0.32 \pm 0.02 \mathrm{~b}$ \\
Triglyceride, mmol/L & $0.25 \pm 0.02 \mathrm{a}$ & $0.19 \pm 0.00 \mathrm{~b}$ & $0.17 \pm 0.01 \mathrm{~b}$ \\
Total cholesterol, mmol/L & $2.14 \pm 0.15 \mathrm{a}$ & $1.83 \pm 0.01 \mathrm{~b}$ & $1.68 \pm 0.09 \mathrm{~b}$ \\
Hepatic Functionality & & & \\
AST,U/L & $78.83 \pm 5.49 \mathrm{a}$ & $68.83 \pm 1.35 \mathrm{~b}$ & $66.33 \pm 1.99 \mathrm{~b}$ \\
ALT, U/L & $15.94 \pm 0.53 \mathrm{a}$ & $12.48 \pm 0.29 \mathrm{~b}$ & $12.33 \pm 0.28 \mathrm{~b}$ \\
Protein metabolism & & & \\
BUN, mmol/L & $5.58 \pm 0.09 \mathrm{a}$ & $5.03 \pm 0.21 \mathrm{~b}$ & $4.97 \pm 0.07 \mathrm{~b}$ \\
Total protein, g/L & $62.58 \pm 1.85 \mathrm{~b}$ & $67.79 \pm 1.10 \mathrm{a}$ & $68.60 \pm 1.06 \mathrm{a}$ \\
Creatinine, $\mu$ mol/L & $57.97 \pm 0.25$ & $58.26 \pm 0.80$ & $58.47 \pm 0.75$ \\
Creatine kinase, U/L & $89.53 \pm 2.11 \mathrm{a}$ & $77.98 \pm 1.78 \mathrm{~b}$ & $78.40 \pm 2.09 \mathrm{~b}$ \\
\hline
\end{tabular}

Means within the same row direction with different superscripts are significantly different $(P<0.05)$.

$P G O=$ control treatment without of $P G$.

$P G 1=$ ration contained $10 \%$ of $P G$.

$P G 2=$ ration contained $20 \%$ of $P G$. 


\section{Economical efficiency $(\mathrm{EE})$ :}

Goats of PG1or PG2 showed higher EE 50.64 and 53.58\% respectively than $36.30 \%$ PG0 goats (Table 8). The highest milk yield and total price of selling milk were shown of goats in PG2 (426.96 kg and 2348.28 L.E) following by (400.10 kg and 2200.55 L.E) PG1 compared to (298.45kg and 1614.84 L.E) PG0 group, respectively. The feed consumption during milking up to 21 st weeks was higher in PG0 $(1380.33 \mathrm{~kg})$ than both PG1 $(1306.22 \mathrm{~kg})$ and PG2 $(1275.42 \mathrm{~kg})$. The feed cost of three dietary groups was absolutely different. The costs were highest in PG0 goats (4521.70 L.E) followed by PG2 (4382.66 L.E) and lastly in PG1 (4345.78.E). The difference of the EE (\%) relative to control among the groups was higher in PG2 (150.00\%) following by PG1 $(141.67 \%)$ than PG0 (100\%). Milk yield was higher in high energy dietary group with PG2; it happened due to high energy. In this context some authors confirmed that high energy containing rations may be used for rising commercial milk of dairy animals (Chiofalo, 2007, Lien et al., 2010, Santos et al., 2017 and El-Sawah et al., 2019 ) they revealed that there was a positive correlation between increase of energy in dietary and milk production.

Table (8): Economical efficiency as affected by propylene glycol supplementation during milking period up to $21^{\text {st }}$ weeks.

\begin{tabular}{lccc}
\hline Attribute & \multicolumn{3}{c}{ Treatments } \\
\cline { 2 - 4 } & PG0 & PG1 & PG2 \\
\hline Total milk yield /group, kg & 298.45 & 400.10 & 426.96 \\
Price of milk selling, L.E A & 1881.43 & 2600.65 & 2775.24 \\
Feed consumption/group/ from:- & 1384.70 & 1305.40 & 1270.10 \\
CFM, kg & 829.96 & 725.00 & 667.67 \\
BH, kg & 365.15 & 370.44 & 376.61 \\
RS, kg & 185.22 & 186.98 & 184.34 \\
PG, kg & 0.00 & 23.80 & 47.60 \\
Total feeding consumption, kg & 1380.33 & 1306.22 & 1275.42 \\
CFM cost, L.E & 3734.82 & 3262.50 & 3004.52 \\
BH cost, L.E & 657.27 & 666.79 & 677.90 \\
RS cost, L.E & 129.61 & 130.89 & 129.04 \\
PG cost, L.E & 0.00 & 285.60 & 571.20 \\
Feeding cost, L.E ${ }^{\text {B }}$ & 4521.70 & 3445.78 & 4382.66 \\
Economic efficiency (EE) amount, ${ }^{\text {A/B }}$ & 0.36 & 0.51 & 0.54 \\
Economic efficiency (EE)\%, A/B $\times 100_{\text {EE (\%) relative to control }}$ & 36.30 & 50.46 & 53.58 \\
\hline
\end{tabular}

The price of selling kg of goat milk at merchant is 5.50 L.E.

The price of feeding consumption in the 2018 for CFM, BH, RS and PG were 4500, 1800, 700 and 12000

L.E / ton, respectively.

$P G O=$ control treatment without of $P G$.

$P G 1=$ ration contained $10 \%$ of $P G$.

$P G 2=$ ration contained $20 \%$ of $P G$.

\section{CONCLUSION}

The use of PG in dairy goats rations instead of 10 or $20 \%$ CFM could be enriched diet, improved nutritional status and consequently has goodness effective on productive performances (as body weight, reproductive measurements post-partum, milk production, feed consumption and blood metabolic) and also hasn't any adverse effective on general healthy status of dairy goats during critical transition period. In general, PG (as previously dosage observed) presents an interesting nutritional strategy for the economic benefits of dairy goat farms 


\section{REFERENCES}

Abdel-Gawad, A. M., H. R. Behery, G. I. El-Emam, T. H. El-Sawah, W. M. Sadek, and E. I. Khalifa (2017). Effect of refused sesame seeds for manufacturing supplement on reproductive and productive performance of dairy goats. Egyptian Journal of Sheep and Goat Sciences, 12 (3): 119 - 135.

Abdel-Latif, M. A., E. S. EL-Gohary, A. A Gabr, A. F. El-Hawary, S. A. Ahmed, S. A. Ebrahim and M. M. Fathala (2016). Impact of supplementing propylene glycol and calcium propionate to primiparous buffalo cows during the late gestation and early lactation period on reproductive performance and metabolic parameters. Alexandria Journal of Veterinary Sciences, 51 (1): 114-121.

Addah, W., A. Ayantunde and E. K. Okine (2017). Effects of restricted feeding and re-alimentation of dietary protein or energy on compensatory growth of sheep. South African Journal of Animal Science, 47 (3): 389-398.

Akamatsu, H., H. Uruma, T. Seto, M. Hurumoto, K. Nakashima, Y. Shinozuka and K. Kawai (2018). Preventative effect of oral administration of propylene glycol and bypass amino acids on the development of ketosis in dairy cows. Asian Journal of Animal and Veterinary Advances, 13 (1): 91 95.

Al-Bulushi, S., T. Shawaf, and A. Al-Hasani (2017). Some hematological and biochemical parameters of different goat breeds in Sultanate of Oman. Veterinary World, 10(4): 461-466.

AOAC (2007). Association of Official Analytical Chemists. Official Methods of Analysis. $19^{\text {th }}$ Edition. Washington, DC: AOAC. USA.

Ayoub, Azza, G. M., Magda M. M. Sabah and Amal I. El-Shorbagi (2015). Effect of propylene glycol supplementation to feed of dairy cows on some biochemical measurements. Egypt Journal Chemistry Environmental Health, 1 (1):899-913.

Barbosa, L. P., M.T. Rodrigues, J. D.Guimarães, V. V. Maffili, L. S. Amorim and N. A. F. Garcez (2009). Condição corporal ao parto e perfil metabólico de cabras alpinas no início da lactação. Revista Brasileira de Zootecnia, 38 :2007-2014.

Bulent, E. (2018) Using and Side-effects of propylene glycol in Animals. Journal of Contraceptive Studies, 3 (2):13.

Candyrine, S. C., M. F. Jahromi, M. Ebrahimi, W. L. Chen, S. Rezaei, Y. M. Goh, N. Abdullah, and J. B. Liang (2018). Oil supplementation improved growth and diet digestibility in goats and sheep fed fattening diet. Asian-Australas Journal Animal Science, 32 (4): 533-540.

Chiofalo, V. (2007). Effect of propylene glycol addition to the diet of dairy ewes on metabolic profile, milk yield and quality. Options Mediterraneennes, 74: 395-398.

Chiofalo, V., S. D’Aquino, E. Scinardo Tenghi, L. Sanzarello, B. Chiofalo, F. Piccitto, M. Cavallaro and L. Liotta (2009). Effect of peripartal propylene glycol supplementation on some biochemical parameters in dairy goats. Tropical and Subtropical Agroecosystems, 11: 215- 217.

Chung, Y., I. Girard and G. Varga (2009). Effects of feeding dry propylene glycol to early postpartum Holstein dairy cows on production and blood parameters. Animal, 3: 1368-1377.

Cruz, W. F. G., G. L. Macedo Junior, M. E. B. Andrade, E. B. Shultz and V. J. C. Rodrigues and S. P. Silva (2014). Consumo, digestibilidade e parâmetros fisiológicos de ovelhas suplementadas com níveis crescentes de propilenoglicol na água. Veterinária Notícias, 20 (1): 19-27.

El-Sawah, T. H, G. E. El-Emam, A. M. Abdel-Gawad and E. I. Khalifa (2019). Impact of propylene glycol on some nutritional, chemical and technological properties of dairy goats. Journal of Food and Dairy Sciences Mansoura University, 10(2):37-45.

El-Tarabany, M. S., A. A. El-Tarabany and E. M. Roushdy (2018). Impact of lactation stage on milk composition and blood biochemical and hematological parameters of dairy Baladi goats. Saudi Journal of Biological Sciences, 25:1632-1638.

Gutierrez, C. G., S. Ferraro and V. Martinez (2011). Increasing ovulation quota: more than a matter of energy. Acta Scientiae Veterinariae, 39 (1):305 - 316. 
Hackbart, K. S., R. W. Bender, P. D. Carvalho, L. M. Vieira, A. R. Dresch, J. N. Guenther, H. Gencoglu, A. B. Nascimento, R. D. Shaver and M. C. Wiltbank (2017). Effects of propylene glycol or elevated luteinizing hormone during follicle development on ovulation, fertilization, and early embryo development. Biology of Reproduction, 97(4):550-563.

Hamzaoui, S., A. A.K. Salama, G. Caja, E. Albanel and X. Such (2014) Effects of supplementation with propylene glycol in heat-stressed dairy goats. Journal Animal Science, 92 (2):736-741.

Hussein, H. A., S. M. Abdel-Raheem, M. Abd-Allah and W. Senosy (2015). Effects of propylene glycol on the metabolic status and milk production of dairy buffaloes. Tierärztliche Praxis Großtiere, $43(\mathrm{G})$ : $1-10$.

Kafilzadeha, F., S. Payandeha, P. Gomez-Cortes, D. Ghadimic, A. Schiavoned and A. L. M. Marıne (2019). Effects of probiotic supplementation on milk production, blood metabolite profile and enzyme activities of ewes during lactation. Italian Journal of Animal Science, 18 (1):134-139.

Khalifa, E. I., A. M. Abdel-Gawad, H. R, Behery, G. I. El-Emam and T. H. El-Sawah (2016A). Reproductive and productive performance of lactating goats quaffed linseed oil and sunflower oil. Egyptian Journal of Sheep \& Goat Sciences, 11(2): 15- 29.

Khalifa, E.I., Hanan A.M. Hassanien, A. H. Mohamed, A. M. Hussein, Azza, A. M. Abd-Elaal and Azza, M. M. Badr (2016B). Influence of addition Spirulina Platensis Algae powder on reproductive and productive performance of dairy Zaraibi goats. Egyptian Journal Nutrition and Feeds, 19 (2):251-265.

Kristensen, N. B. and B. M. L. Raun (2007). Ruminal and intermediary metabolism of propylene glycol in lactating Holstein cows. Journal Dairy Science, 90: 4707- 4717.

Lien, T. F., L. B. Chang, Y. M. Horng and C. P. Wu (2010). Effects of propylene glycol on milk production, serum metabolites and reproductive performance during the transition period of dairy cows. Asian-Australian Journal Animal Science, 23 (3): 372-378.

Liu, Q. I., C. Wang, W. Z. Yang, W. W. Zhang, X. M. Yang, D. C. He, K. H. Dong and Y. X. Huang (2009). Effects of feeding propylene glycol on dry matter intake, lactation performance, energy balance and blood metabolites in early lactation dairy cows. Animal, 3(10):1420-1427.

Ma, T., F. Wan, D. Yang, K. Deng, K. Yang and Q. Diao (2019). Growth performance, nutrient digestibility, and slaughter traits of male fattening lambs under different feeding standards. Animal Nutrition, 5(1): 74-79.

Magistrelli, D. and F. Rosi (2014). Trend analysis of plasma insulin level around parturition in relation to parity in Saanen goats. Journal Animal Science, 92:2440-2446.

Mecitoğlu, Z., S. Ç. Kasap, M. L. Özdüven, M. Özder and E. Kennerman (2017). Effects of prepartum treatment with monensin or propylene glycol mixed with concentrate on milk yield and blood NEFA and BHBA levels in dairy cows. Turkish Journal of Veterinary and Animal Sciences, 41: 667-671.

Nalawade, T. M., K. Bhat and S. H. P. Sogi (2015). Bactericidal activity of propylene glycol, glycerin, polyethylene glycol 400, and polyethylene glycol 1000 against selected microorganisms. Journal of International Society of Preventive \& Community Dentistry, 5: 114-119.

NRC (2007). Nutrient requirements of small ruminants: Sheep, goats, cervids, and new world camelids, National Academies Press, Washington, D.C., U.S.A.

Prasannkumar, R. V., R. G. Jani, H. V. Goswami, S. D. Rathwa and F. B. Tandel (2016) Studies on clinical signs and biochemical alteration in pregnancy toxemic goats. Veterinary World, 9(8): 869874.

Praveen, K., K. Ravikanth, S. Maini and A. Reothia (2015). Pregnancy toxemia treatment with polyherbal formulation in ewes. International Journal of Therapeutic Applications, 28: 28-33.

Rekik, M., N. Lassoued, H. Ben Salem and I. Tounsi (2005). Reproductive traits of Queue Fine de líOuest ewes fed on wheat straw supplemented with concentrate and Acacia cyanophylla Lindl. foliage with and without PEG. Small Ruminant Research, 70:352-357.

Rekik, M., N. Lassoued, H. Ben Salem and M. Mahouachi (2007). Interactions between nutrition and reproduction in sheep and goats with particular reference to the use of alternative feed sources. Série A. Séminaires Méditerranéens, 74: 375-383. 
Rinne, M., S. Jaakkola and P. Huhtanen (1997). Grass maturity effects on cattle fed silage-based diets. 1. Organic matter digestion, rumen fermentation and nitrogen utilization. Animal Feed Science Technology, 67: 1-17.

Rukkwamsuk, T. and S. Panneum (2010). Effect of oral administration of propylene glycol during periparturient period on blood biochemical parameters and liver triacylglycerol accumulation in postparturient dairy cows. African Journal of Agricultural Research, 5 (23): 3239-3245.

Sadjadian, R., H. A. Seifi, M. Mohri, A. A. Naserian and N. Farzaneh (2013a). Variations of energy biochemical metabolites in periparturient dairy Saanen goats. Comparative Clinical Pathology, 22: 449-456.

Sadjadian, R., H. A. Seifi, M. Mohri, A. A. Naserian and N. Farzaneh (2013b). Effects of monensin on metabolism and production in dairy Saanen goats in periparturient period. Asian-Aust. Journal Animal Science, 26(1): 82-89.

Santos, R. P., G. L. M. Junior, S. P. Silva, L. F. Sousa and M. E. B. Andrade (2017). Inclusion of propylene glycol in the diet of sheep and its effect on their lambs' protein and mineral metabolites. Acta Scientiarum. Animal Sciences, 39 (3): 297-302.

Shankare Gowda, A. J., M. Devaraj and A. Krishnaswamy (2013). The influence of feeding propylene glycol, rumen protected- fat and protein on milk yield in early lactating cows. International Journal of Science and Research, 4 (7): 1254-1257.

Soares, F. A. P., N. A.V. Borba, I. B Freitas, C. C. D. Carvalho, J. D. Barbosa and P. C. Soares (2014). Clinical biochemistry or energy and protein metabolism in Dorper ewes during pregnancy and postpartum. Revista de Ciências Agrárias, 57: 267-272.

SPSS (2018). Statistical package for social sciences, IBM®SPSS Statistics Data Editor 25.0 License Authorization Wizard, Chicago, USA.

Van Soest, P. J., J. B. Robertson and B. A. Lewis (1991). Methods for dietary fiber, neutral detergent fiber, and no starch polysaccharides in relation to animal nutrition. Journal Dairy Science, 74: 35833597.

Vasava, P. R., R. G. Jani, H. V. Goswami, S. D. Rathwa and F. B. Tandel (2016). Studies on clinical signs and biochemical alteration in pregnancy toxemic goats. Veterinary World, 9 (8): 869-874.

Viñoles, C., B. Paganoni, K. M. M. Glover, J. T. B Milton, D. Blache, M. A. Blackberry and G. B. Martin (2010). The use of a 'first wave' model to study the effect of nutrition on ovarian follicular dynamics and ovulation rate in the sheep. Reproduction Research, 140: 865-874.

Xu, G. S., T. Ma, S. K. Ji, K. D. Deng, Y. Tu and C. G. Jiang (2015). Energy requirements for maintenance and growth of early-weaned Dorper crossbred male lambs. Livest Science, 177:71-78.

Yadav, S. N., D. N. Kalita, A. Phukan, B. C. Das, T. C. Dutta, G. Mahato, S. Tamuly, D. Barman and K. Bharali (2018). A comparative therapeutic study on subclinical ketosis of goat. Journal of Entomology and Zoology Studies, 6(3): 673-676

Yisehak, K., J. De-Boever, and G. P. J. Janssens (2013). The effect of supplementing leaves of four tannin-rich plant species with polyethylene glycol on digestibility and zootechnical performance of zebu bulls (Bos indicus). Journal of Animal Physiology and Animal Nutrition, 98: 431-438. 


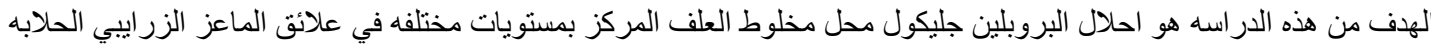

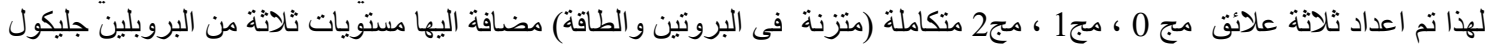

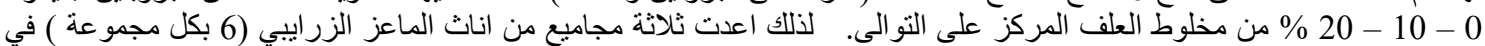

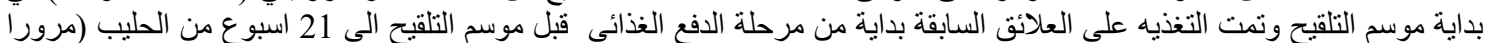

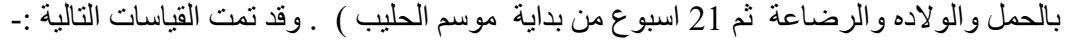

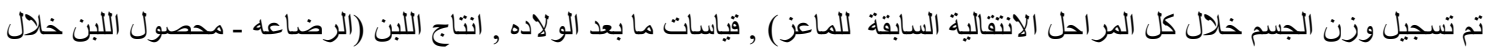

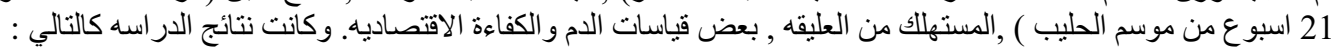
- وجد ان كلا من المجمو عتنين مج1 (10\%) ومج2 (20\%) تفوقتا في وزن الجسم بمعنويه خلال جميع المر احل الانتقاليه بالمقارنه مع

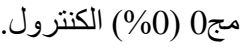
- وجد ان المجمو عتين الثانية و الثالثة اعطت تحسنا في جميع قياسات ما بعد الو لادة عن الدجمو عة الكنترول .

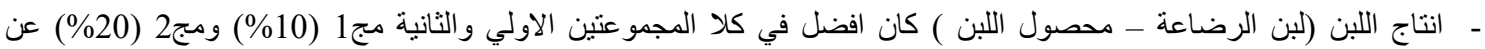

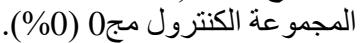

ـ ـ وجد ان المستهلك من المادة الجافه كان منخفضا بمعنويه في كلا المجمو عتين الثانية و الثالثة عن المجمو عة الكنترول.

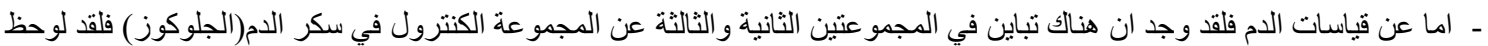

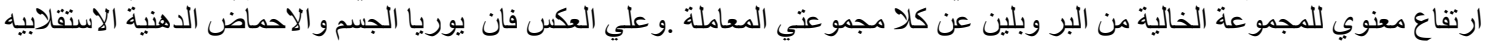

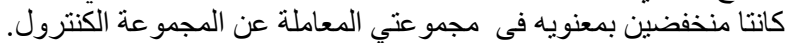

- بدراسة الكفاءة الاقتصادية لبيع اللبن المنتج لكل مج1,مج2 للبروبلين جليكول كان اعلي في القيمه الماديه عن مج1 .

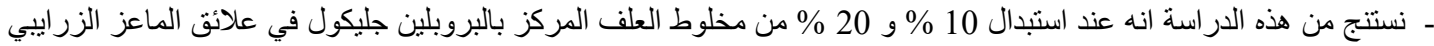

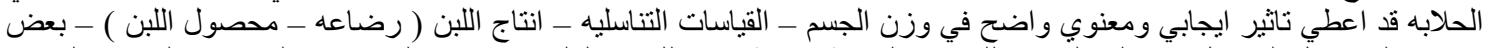

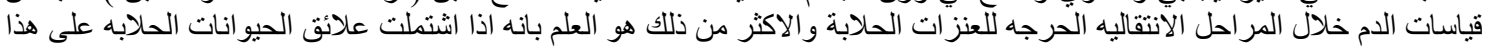
المركب البروبلين جليكول ستعطي القتصاديه عاليه في انتاج الالبان. 